\title{
Analisis Implementasi Smart Society melalui Program Gerbang Hebat di Kota Semarang
}

\author{
Agustina Rahmawati, Hanantyo Sri Nugroho \\ Program Studi Ilmu Pemerintahan, Universitas AMIKOM Yogyakarta, Sleman, Indonesia
}

\begin{tabular}{l}
\hline ARTICLE INFORMATION \\
\hline Received: February 26, 2021 \\
Revised: March 26, 2021 \\
Accepted: April 29, 2021 \\
Available online: April 24, 2021 \\
KEYWORDS \\
\hline Semarang City, Program Gerbang Hebat, Public \\
Service Implementation \\
CORRESPONDENCE
\end{tabular}

Phone: 085642858885

E-mail: agustinarahma@amikom.ac.id

\section{PENDAHULUAN}

Permasalahan yang dihadapi oleh kota semakin kompeks sehingga membutuhkan penanganan yang responsif. Beberapa permasalahan yang muncul adalah kemiskinan, sampah, kemacetan, pangan, dan kurangnya ruang terbuka hijau. Hal tersebut kemudian mendorong pemerintah kota untuk melakukan inovasi yang responsif. Pada saat ini, inovasi yang responsif tersebut kemudian membawa konsekuensi pada pengembangan smart city. Terdapat tiga karakteristik klaster utama yang dapat diukur dari smart city yakni smart economy, smart society, dan smart environment (Supangkat \& Arman, 2018). Lebih lanjut, terdapat ruang lingkup pada pada karakteristik klaster utama tersebut yakni l) smart economy merupakan pengelolaan berbasis smart solution yang melihat pada potensi yang dimiliki oleh wilayah/kota, 2) smart society merupakan pengelolaan berbasis smart solution yang melihat pada pengelolaan kekuatan organisasi kemasyarakatan dalam merespons perubahan yang terjadi di wilayah/kota tersebut, 3) smart environment merupakan pengelolaan berbasis smart solution yang melihat pada pendekatan solusi terhadap permasalahan yang terjadi di wilayah/kota tersebut.

Penerapan smart city di kota Semarang sudah mulai dibangun sistemnya sejak tahun 2013, ketika Walikota Semarang Hendrar Prihadi menandatangani nota kesepahaman dengan PT Telkom mengenai pemanfaatan teknologi, informasi dan komunikasi sebagai upaya mewujudkan program digital government service melalui kota cerdas di wilayah Kota Semarang. Meskipun demikian, regulasi selesai dirumuskan pada tahun 2018 yakni melalui Peraturan Walikota Semarang Nomor 26 Tahun 2018 tentang Rencana Induk Semarang Kota
Cerdas (Masterplan Semarang Smart City). Dalam peraturan tersebut menjelaskan bahwa untuk mewujudkan Semarang Kota Cerdas menggunakan konsep keberlanjutan, konektivitas, kreativitas dan keterpaduan sosial untuk mencapai pengambangan enam dimensi smart yang terdiri dari smart governance, smart branding, smart economy, smart living, smart society dan smart environment dalam rangka merealisasikan program prioritas yang tertera pada Rencana Pembangunan Jangka Menengah Daerah (RPJMD) Kota Semarang tahun 2016-2021 (Peraturan Walikota Semarang Nomor 26 Tahun 2018 Tentang Rencana Induk Semarang Kota Cerdas (Masterplan Semarang Smart City), 2018). Pada pengembangan Semarang Kota Cerdas tahun pertama cenderung dilaksanakan pada program pengembangan internal melalui cyber governance diantaranya penyiapan kebijakan, sumber daya manusia, aplikasi dan infrastruktur. Lebih lanjut, salah satu dimensi kota cerdas yang dilaksanakan kota tersebut yakni smart society. Smart society pada kota Semarang merupakan upaya tata kelola untuk mewujudkan ekosistem sosio-teknis masyarakat yang humanis dan dinamis baik secara fisik maupun masyarakat yang produktif, komunikatif, dan interaktif dalam mengatasi permasalahan yang muncul, salah satunya kemiskinan.

Kemiskinan adalah salah satu masalah utama yang dialami oleh kota-kota di Indonesia, sehingga membutuhkan penanganan yang terintegrasi dan berkelanjutan. Berdasarkan data BPS, kenyataannya adalah bahwa tingkat kemiskinan di daerah perkotaan juga masih tinggi yaitu 6,56\% (BPS, 2020). Oleh karena itu, diperlukan sinergi dan dukungan dari semua pihak antara pemerintah pusat, pemerintah provinsi dan pemerintah daerah, sektor swasta, serta masyarakat dalam 
mengimplementasikan program pengurangan kemiskinan sebagai upaya meningkatkan kesejahteraan masyarakat. Penelitian tentang implementasi program kemiskinan telah banyak dilakukan. Studi-studi ini mengkaji berbagai jenis program yang dijalankan pemerintah dalam upaya mengentaskan kemiskinan. Pertama, penelitian tentang implementasi program pengurangan kemiskinan yang dipercepat oleh Kantor Kesejahteraan Sosial Kota Samarinda (Awaliyah Rizky, 2016). Hasil penelitian menunjukkan bahwa kelompok sasaran baru mencapai $80 \%$, perubahan yang diinginkan telah meningkatkan pendidikan dan kesehatan masyarakat tetapi belum mampu meningkatkan kesejahteraan ekonomi dan belum mampu mengurangi jumlah orang miskin di Kota Samarinda. Kedua, penelitian tentang implementasi kebijakan program pengurangan kemiskinan melalui kartu penjamin sosial dan kartu indonesia pintar untuk masyarakat pada studi kasus di Desa Kauman, Kota Malang (Sulhan \& Sasongko, 2017). Hasil kebijakan menunjukkan bahwa pengelompokan masyarakat dilakukan oleh petugas terkait untuk memfasilitasi distribusi KPS dan KIP khususnya masyarakat Kecamatan Kauman yang populasinya mencapai 560 orang ditemukan bahwa penduduk miskin memiliki hak untuk menerima sebanyak 30\% dari KPS sementara yang miskin memiliki 5\%. Lebih lanjut, studi-studi sebelumnya memiliki keterbatasan, yaitu kurang mendalam dalam menganalisis berbagai faktor yang berkontribusi pada keberhasilan pengurangan kemiskinan tanpa melihat dukungan indikator Smart Society yang telah diluncurkan oleh Pemerintah Pusat melalui inovasi kota pintar di berbagai kota. Artinya, Smart Society yang kemudian memunculkan konsekuensi bahwa pengembangan teknologi dan komunikasi berbasis digitalisasi layanan dan tata kelola harus diselaraskan dengan pembangunan manusia. Ini bertujuan untuk membuat pengembangan kota pintar sesuai dengan nilai-nilai kemanusiaan seperti partisipasi dan nilai-nilai lokal, serta kebutuhan masyarakat yang ada. Dengan demikian, perkembangan smart society dalam mengimplementasikan kota pintar adalah masalah yang menarik untuk dipelajari.

Salah satu program Pemerintah Kota Semarang dalam mewujudkan smart society adalah Gerakan Bersama Penanggulangan Kemiskinan Dan Pengangguran Melalui Harmonisasi Ekonomi, Pendidikan, Etos Dan Ekosistem Masyarakat (Gerbang Hebat) berusaha mendukung upaya peningkatan kesejahteraan masyarakat melalui sinergitas berbagai stakeholder dan integrasi pusat pelayanan informasi publik yang mudah diakses oleh masyarakat. Melalui program Gerbang Hebat diharapkan mampu mewujudkan smart society. Oleh karena, kota cerdas itu tidak hanya mengenai teknologi informasi (TI) tetapi juga dapat berupa dukungan non teknologi informasi (TI) sehingga Pemerintah Kota Semarang pada tahapan lebih lanjut berupaya melibatkan berbagai pihak untuk bekerjasama melalui unsur pentahelix yakni akademisi, bisnis, community, government dan media (ABCGM). Upaya percepatan pengentasan kemiskinan terus dilakukan oleh berbagai kota di Indonesia melalui berbagai inovasi yang dilakukan oleh masing-masing kepala daerah melalui peta jalan kota pintar. Salah satunya yang memiliki roadmap kota pintar adalah Pemerintah Kota Semarang. Selanjutnya, telah banyak upaya telah dilakukan untuk mendukung realisasi menjadi kota yang cerdas. Sementara itu, langkah yang diambil oleh Pemerintah Kota Semarang adalah menciptakan integrasi atau sinergi antar pemangku kepentingan dalam keterkaitan untuk menciptakan Smart Society. Hal ini karena salah satu elemen penting dalam kota pintar adalah masyarakat. Dalam perkembangannya, Pemerintah Kota Semarang telah memprakarsai program pengentasan kemiskinan yaitu Program Gerbang Hebat. Dilihat dari sudut pandang pembangunan sosial, menjadi penting untuk harmoni bagi pertumbuhan ekonomi, stabilitas politik, dan harmoni sosial. Harmoni tersebut tentang merancang dan mengembangkan solusi Smart City dengan cara yang akan memberikan nilai kepada warga (Heaton \& Parlikad, 2019). Penekanan pada peran teknologi informasi dan komunikasi dalam proses partisipasi warga negara dan kontribusinya yang signifikan terhadap sosial keberlanjutan dan penciptaan kota pintar yang lebih dari manusia (Bouzguenda, 2019). Oleh karena itu, partisipasi warga berbasiskan digitalisasi, dalam memberikan umpan balik layanan, secara positif terkait dengan tingkat izin perkotaan permintaan layanan di unit layanan kecamatan, setelah mengendalikan berbagai faktor (Allen et al., 2019). Pada saat ini, sangat tepat bagi Pemerintah Kota Semarang untuk mengambil jalan tengah dan menganggap pembangunan sosial dan ekonomi sebagai serangkaian hubungan sebab akibat yang saling terkait secara sinergis. Oleh karena, konsep Smart City beradaptasi dengan kekuatan ekonomi dan sosial yang paling kuat di zaman kita kebutuhan tempat di mana sebagian besar dari kita tinggal dan bekerja (Patel \& Doshi, 2019). Lebih lanjut, tingkat kegunaan yang diambil dari evaluasi berbasis tugas tidak terkait langsung dengan integrasi dokumen batas ke situs web pemerintah (Fietkiewicz et al., 2017). Akan tetapi, bagaimana warga negara berinteraksi dengan pemerintah di era kemunculan orang pintar kota, dan bagaimana interaksi ini berdampak pada hubungan antara warga dan pemerintah, memperkenalkan hal baru jalan untuk pengaruh sektor swasta (Johnson et al., 2019). Selain itu, terdapat faktor kepemilikan lokal dan penyediaan struktur untuk perencanaan kota yang lebih inklusif (Horgan \& Dimitrijević, 2019). Adapun, identifikasi driver strategis yang dapat membantu penguasa kota pintar dalam pengembangan kebijakan publik dan tindakan eksekutif kota yang melibatkan populasi untuk mencapai tujuan pembangunan berkelanjutan (De Guimarães et al., 2020). Dengan demikian, Smart Society yang kemudian memunculkan konsekuensi bahwa pengembangan teknologi dan komunikasi berbasis digitalisasi layanan dan tata kelola harus diselaraskan dengan pembangunan manusia.

Lebih lanjut, penelitian ini akan menganalisis faktor-faktor pendorong dan penghambat dalam pelaksanaan Program Gerbang Hebat sebagai upaya untuk mewujudkan Smart Society di kota Semarang. Dalam menganalisis masalah penelitian, peneliti menggunakan teori implementasi kebijakan dari Van Meter dan Van Horn (Agustino, 2006) untuk melihat faktor-faktor yang berkontribusi terhadap implementasi Program Gerbang Hebat sebagai manifestasi Smart Society, yang terdiri dari l) standar dan target kebijakan. Kinerja implementasi kebijakan dapat diukur dengan tingkat keberhasilan jika dan hanya ukuran dan tujuan kebijakan yang realistis dengan sosial-budaya di tingkat implementasi.; 2) sumber daya organisasi. Tahapan-tahapan tertentu dari keseluruhan proses implementasi membutuhkan keberadaan sumber daya manusia yang berkualitas sesuai dengan pekerjaan yang diperlukan oleh kebijakan yang ditentukan secara politis. Terlepas dari sumber daya manusia, sumber daya keuangan dan 
sumber daya waktu juga dihitung yang sering menjadi masalah publik untuk mewujudkan tujuan kebijakan publik.; 3) komunikasi antara lembaga pelaksana. Koordinasi adalah mekanisme yang kuat dalam implementasi kebijakan publik. Semakin baik koordinasi komunikasi antara para pihak yang terlibat dalam proses implementasi, asumsinya adalah bahwa kesalahan akan sangat kecil terjadi.; 4) karakteristik lembaga pelaksana. Kinerja implementasi kebijakan akan sangat dipengaruhi oleh karakteristik dan kompatibilitas yang tepat dengan lembaga pelaksana. Misalnya, menerapkan kebijakan publik yang berupaya mengubah perilaku atau tindakan manusia secara radikal, maka badan pelaksana proyek harus dicirikan oleh aturan dan sanksi hukum yang ketat dan ketat.; 5) keadaan lingkungan. Sejauh mana lingkungan eksternal berkontribusi terhadap keberhasilan kebijakan publik yang telah dilaksanakan. Lingkungan sosial, ekonomi dan politik yang tidak kondusif dapat menjadi penyebab kegagalan kinerja implementasi kebijakan.; 6) menerapkan sikap. Kebijakan yang akan diterapkan oleh pelaksana adalah kebijakan top-down yang sangat mungkin bahwa pembuat keputusan tidak tahu atau tidak mampu menyentuh kebutuhan, keinginan, atau masalah yang ingin diselesaikan orang.

\section{METODE}

Penelitian ini dilakukan di Kota Semarang. Penelitian ini menggunakan penelitian deskriptif kualitatif. Oleh karena itu, peneliti bermaksud mendeskripsikan bagaimana implementasi program Gerbang Hebat dalam perwujudan Smart Society di Kota Semarang. Dalam hal ini, penelitian deskriptif umumnya dilakukan dengan tujuan utama, yaitu untuk secara sistematis menggambarkan fakta dan karakteristik objek atau subjek yang diteliti secara tepat. Selain itu, banyak metode penelitian deskriptif juga dilakukan oleh peneliti karena metode deskriptif sangat berguna untuk mendapatkan berbagai masalah yang berkaitan dengan bidang pendidikan dan perilaku manusia (Sukardi, 2003).

Tahapan awal penelitian dilakukan dengan memetakan masalah, teori, dan peraturan yang berkaitan penelitian ini. Oleh karena itu, tahap ini mencakup diskusi internal dengan Ibu Dwi Wahyu Ratna Damayanti, SH sebagai Pengelola Program dan Kegiatan, serta Ibu Sulamatul Fatiroh, A.Md.SST sebagai Analis Perencanaan pada Badan Perencanaan Pembangunan Daerah Kota Semarang. Hal ini bertujuan untuk menemukan peraturan, dokumen kerja sama, dan referensi terkait lainnya. Pada pengumpulkan data, penelitian ini mengumpulkan data melalui persilangan berbagai sumber data yang berasal dari studi literatur, observasi dan wawancara. Selanjutnya, reduksi data dilakukan pada data yang telah diperoleh dengan merangkum data, memilah poin utama dan fokus pada hal-hal yang terkait dan juga penting untuk penelitian ini. Instrumen yang digunakan oleh peneliti adalah alat tulis, alat perekam, kamera, laptop.

\section{HASIL DAN PEMBAHASAN}

Pelaksanaan program Gerakan Bersama Penanggulangan Kemiskinan Dan Pengangguran Melalui Harmonisasi Ekonomi, Pendidikan, Etos Dan Ekosistem Masyarakat (Gerbang Hebat) di Kota Semarang dilakukan melalui 3 (tiga) kegiatan yaitu Desa Tematik, program e-warung Kelompok Bisnis Bersama (KUBE), dan Duta Revolusi Mental Rumah (RDRM). Pada pelaksanaan program Kampung Tematik, dukungan program ini diperoleh dari banyaknya bantuan Corporate Social Responsibility (CSR) dari pihak swasta, perbankan, BUMN/BUMD baik berupa infrastruktur dan lain-lain. Selain itu, terdapat juga dukungan dari pemerintah dan stakeholder terkait dengan pelaksanaan program Kampung Tematik tersebut. Pada perkembangannya, terdapat beberapa kendala pada pelaksanaan program kampung tematik yakni terkait dengan pengelolaan wisata kampung berbasis komunitas masih rendah sehingga tingkat kepedulian masyarakat dalam pemeliharaan cenderung rendah, masih terdapat stigma negatif masyarakat terhadap bantuan pemerintah, serta terdapat persaingan ekonomi pada UMKM yang ada. Meskipun demikian, diharapkan program Kampung Tematik ini natinya dapat meningkatkan daya tarik wisatawan berkunjung, meningkatkan pendapatan ekonomi masyarakat kampung, banyaknya UMKM yang bekembang dan bermunculan di kampung, serta terbukanya akses bagi masyarakat yang ingin mengembangkan usahanya di kampung. Artinya, program Kampung Tematik dapat memunculkan keuntungan bagi masyarakat atas peluang yang ada pada program tersebut. Selanjutnya, pada pelaksanaan program e-warung Kelompok Bisnis Bersama (KUBE), dukungan program ini diperoleh dari banyaknya minat ibu-ibu terhadap program, serta adanya kemauan ibu-ibu untuk keluar dari kemiskinan. Hal ini memunculkan konsekuensi atas menggiatnya produktivitas ekonomi masyarakat dan terbukanya akses pengetahuan masyarakat dalam mengakses kebutuhan melalui Electronic Data Card (EDC). Adapun, hambatan yang muncul adalah terkait dengan monitoring evaluasi pemerintah terhadap program kurang optimal sehingga masih terdapatnya penyandang dana yang tidak tepat sasaran, serta indikator penerima bantuan kurang jelas sehingga dapat menjadi ancaman pada saat menghadapi persaingan usaha. Lebih lanjut, pada pelaksanaan program Rumah Duta Revolusi Mental (RDRM), dukungan program ini diperoleh dari fasilitas call center, aplikasi website dan sosial media untuk melayani pengaduan psychological support system yang berbasis teknologi, serta adanya lembaga organisasi yang menangani program tersebut. Hambatan pada program ini berasal dari tingkat partisipasi masih kurang dikarenakan masyarakat masih kurang terbuka untuk melaporkan kasus maupun masalahnya. Kendala tersebut juga didukung oleh gangguan hotline, serta adanya perubahan organisasi dan minimnya sumber daya manusia (SDM) ekspertise yang menangani berbagai permasalahan yang ada. Akan tetapi, program ini masih memiliki manfaat bagi awal terbukanya akses menjadi Resilient City terutama di bidang kesehatan fisik dan psikososial pada anak dan perempuan Kota Semarang, serta terbukanya kerjasama dengan lembaga psikologi. Nantinya, diharapkan program ini dapat mengurangi tingkat traumatik korban kekerasan.

Dengan demikian, upaya mendukung keberlanjutan program ini, masih diperlukan semangat kerja dan komitmen tinggi dari para pelaku yang terlibat dalam kemiskinan pengentasan untuk menciptakan masyarakat yang lebih sejahtera. Penyajian basis data yang valid, akurat, tepat sasaran, objektif, dan terkini dimana berdasarkan nama berdasarkan alamat serta berdasarkan potensi dan wilayah juga masih merupakan tantangan dan pemantauan maupun evaluasi ketika program telah selesai. Selain itu, partisipasi masyarakat memiliki peran penting dalam mewujudkan tata kelola 
masyarakat berbasis digital. Hal ini untuk memastikan bahwa kegiatan yang sesuai dengan kebutuhan masyarakat, serta memastikan bahwa kegiatan ini adalah kegiatan yang berkelanjutan dan dapat membawa masyarakat menuju kemandirian.

\section{Implementasi Kebijakan Program Gerbang Hebat Kota Semarang}

Kota Semarang memiliki visi untuk menjadikan Semarang sebagai kota perdagangan dan jasa yang besar menuju masyarakat yang semakin makmur, dan misi Kota Semarang yakni 1) mewujudkan kehidupan masyarakat yang berbudaya dan berkualitas; 2) mewujudkan pemerintahan yang semakin andal untuk meningkatkan layanan publik; 3) menciptakan kota metropolitan yang dinamis dan berwawasan lingkungan; 4) memperkuat ekonomi rakyat berdasarkan keunggulan lokal dan membangun iklim bisnis yang kondusif. Dalam mewujudkan misinya, Pemerintah Kota Semarang memiliki beberapa kebijakan atau program, salah satunya adalah program untuk meningkatkan kesejahteraan sosial. Program yang memiliki salah satu keunggulan utamanya adalah pengentasan kemiskinan terintegrasi, di mana program tersebut dinamakan program Gerbang Hebat. Program pengentasan kemiskinan terintegrasi Semarang diprioritaskan karena merupakan upaya untuk meningkatkan kesejahteraan masyarakat Kota Semarang. Referensi dasar untuk mengimplementasikan pengurangan kemiskinan di kota Semarang adalah sebagai berikut Undang-Undang Nomor 13 Tahun 2011 tentang Penanganan Orang Miskin; Peraturan Presiden Nomor 15 Tahun 2010 tentang Percepatan Penanggulangan Kemiskinan; Peraturan Menteri Dalam Negeri Nomor 42 Tahun 2010 tentang Tim Koordinasi Penanggulangan Kemiskinan Provinsi dan Kabupaten/Kota (TKPK); Peraturan Daerah Kota Semarang Nomor 4 Tahun 2008 tentang Pengurangan Kemiskinan di Kota Semarang; Peraturan Daerah Nomor 7 Tahun 2015 tentang Program Kemitraan dan Pengembangan Masyarakat sebagai Tanggung Jawab Sosial Perusahaan di Kota Semarang; Peraturan Walikota Semarang Nomor 18C tahun 2009 tentang Indikator, Kriteria dan Klasifikasi Penduduk Miskin Kota Semarang; Peraturan Walikota Semarang Nomor 26 Tahun 2016 tentang Pedoman Pelaksanaan Peraturan Daerah Nomor 7 Tahun 2015 tentang Program Kemitraan dan Bina Lingkungan sebagai Tanggung Jawab Sosial Perusahaan di Kota Semarang; Keputusan Walikota Semarang Nomor 050/680/2015 tanggal 13 Juli 2015 tentang Penentuan Basis Data Penduduk Miskin Kota Semarang pada tahun 2015; Keputusan Walikota Semarang Nomor 050/444 tanggal 24 Mei 2016 tentang Pembentukan Tim Koordinasi Penanggulangan Kemiskinan Kota (TKPKD) Kota Semarang dan Kelompok Program Pengurangan Kemiskinan Kota Semarang; Keputusan Walikota Semarang Nomor 050/457 tanggal 26 Mei 2016 tentang Pembentukan Sekretariat Tim Koordinasi Penanggulangan Kemiskinan Kota (TKPKD) Kota Semarang dan Kelompok Kerja Koordinasi Pengurangan Kemiskinan Kota Semarang. Harapan mengurangi tingkat kemiskinan di Kota Semarang dapat dicapai minimal 1,5\% per tahun sesuai dengan target RJMD Kota Semarang untuk 2016-2021 yang mengamanatkan pencapaian target kemiskinan, yang turun dari 20,82\% pada 2015 hingga 16,45\% pada tahun 2021. Diharapkan 177 Kelurahan di 16 Kecamatan di Semarang akan tersentuh oleh program Gerbang Hebat dalam 5 (lima) tahun. Tahapan didasarkan pada jumlah orang miskin di setiap desa. Desa-desa dengan banyak orang miskin akan menjadi lokasi program pada tahun-tahun awal. Sementara itu, pada tahun-tahun terakhir ada beberapa desa dengan sedikit orang miskin.

Dalam implementasinya, Program Gerbang Hebat menargetkan beberapa bidang yakni bidang ekonomi, bidang pendidikan, bidang etos, bidang ekosistem. Pada bidang ekonomi terdapat pelatihan kewirausahaan, fasilitasi pengembangan bisnis mikro, pelatihan keterampilan, pengembangan perikanan rakyat, bantuan ternak, bantuan untuk warung vokasi desa, bantuan makanan untuk kerawanan pangan, distribusi beras sejahtera, persiapan pekerja siap pakai, pelatihan pemagangan berbasis masyarakat, solid kerja produktif, pembentukan Pengusaha Baru (WUB), santunan kematian bagi orang miskin. Pada bidang pendidikan terdapat bantuan untuk BOS, beasiswa untuk kaum miskin, pengembangan desa kejuruan, mengatur kursus keterampilan, fasilitasi paket pengorganisasian A, B dan C. Pada bidang etos terdapat pelatihan keterampilan untuk Penyandang Masalah Kesejahteraan Sosial (PMKS), bantuan program Keluarga Harapan (PKH), program e-warung Kelompok Bisnis Bersama (KUBE), penyediaan dan layanan perangkat kontrasepsi untuk kaum miskin, bantuan untuk organisasi masyarakat dan lembaga masyarakat, fasilitas pendukung untuk Program Tentara Manunggal Masuk Desa (TMMD). Pada bidang ekosistem terdapat layanan Kesehatan untuk Masyarakat Miskin (Jamkesmaskot), perbaikan sanitasi dasar untuk kaum miskin, pencegahan kekurangan protein, anemia, nutrisi, garam yodium, desa mandiri pangan, peningkatan Perumahan Masyarakat Miskin (RTLH), lingkungan pemukiman yang lebih baik, penanganan dan pengaturan permukiman kumuh, membuat sanitasi komunal, konstruksi dan perbaikan MCK, kontrol dampak perubahan iklim, membuat biopori, peningkatan Ruang Terbuka Hijau (RTH), transportasi murah melalui Bus Rapid Transit (BRT).

\section{Faktor-faktor yang berkontribusi terhadap implementasi Gerbang Hebat sebagai perwujudan Smart Society di Kota Semarang}

Keberhasilan implementasi kebijakan dipengaruhi oleh faktor-faktor yang berkontribusi padanya. Berdasarkan penelitian yang telah dilakukan, ada beberapa faktor yang berkontribusi terhadap implementasi Gerbang Hebat, yakni standar dan sasaran kebijakan, sumber daya organisasi, komunikasi antara lembaga pelaksana, karakteristik lembaga pelaksana, sikap pelaksana, serta keadaan lingkungan.

Pertama, standar dan sasaran kebijakan ditunjukkan oleh kejelasan dan sifat realistis dari kebijakan yang telah dirumuskan. Standar kebijakan program ini merujuk dari beberapa peraturan dari pusat hingga walikota kota Semarang tentang pengentasan kemiskinan dan pengangguran secara terpadu. Dalam kebijakan tersebut sudah sangat jelas terlihat indikator dan sasaran yang telah ditetapkan untuk penerima program Gerbang Hebat tersebut.

Kedua, sumber daya organisasi ditunjukkan oleh seberapa banyak dukungan keuangan dan sumber daya manusia, serta fasilitas dan infrastruktur untuk melaksanakan program atau kebijakan. Sumber daya organisasi baik sumber daya manusia dan sumber daya keuangan, serta sarana dan prasarana merupakan sumber organisasi yang perlu mendapat perhatian. 
Sumber keuangan untuk pelaksanaan program Gerbang Hebat Kota Semarang berasal dari Anggaran Daerah Kota Semarang dan bantuan Corporate Social Responsibility (CSR). Adapun, setiap anggaran kegiatan Gerbang Hebat Kota Semarang telah diatur dan melalui tahap tertentu yang dimulai dengan perencanaan anggaran untuk kemudian diajukan untuk persetujuan. Jumlah anggaran yang disediakan oleh pemerintah kota Semarang untuk implementasi program tidak harus sama setiap tahun. Hal ini kadang-kadang disesuaikan dengan program kerja walikota pada waktu itu. Selain itu, juga ditentukan oleh nilai pagu anggaran yang telah ditentukan untuk setiap Satuan Kerja Perangkat Daerah (SKPD) di Kota Semarang. Penggunaan anggaran selalu merupakan bentuk pertanggungjawaban sebagai kontrol. Bappeda Kota Semarang setiap periode tertentu selalu membuat Surat Pertanggungjawaban (SPJ) untuk setiap kegiatan yang telah dilakukan dalam periode waktu tertentu. Laporan dibuat setiap triwulan untuk melihat apakah anggaran dialokasikan secara maksimal selama tiga bulan. Pemantauan dan evaluasi tidak berasal dari Bappeda Kota Semarang itu sendiri tetapi mengikuti aturan yang dibuat oleh Pemerintah Kota Semarang misalnya dengan kegiatan Surat Pertanggungjawaban (SPJ) setiap bulan yang dilaporkan ke Dinas Pengelolaan Keuangan dan Aset Daerah (DPKAD) dan Inspektorat. Kemudian bentuk lain pemantauan dan evaluasi disampaikan bahwa setiap bulan ada pertemuan laporan kemajuan yang harus dihadiri oleh Satuan Kerja Perangkat Daerah (SKPD) Kota Semarang dan juga dihadiri dan didengarkan secara langsung oleh Walikota Semarang. Pertemuan tersebut terkait dengan laporan anggaran. Bappeda Kota Semarang melakukan laporan kemajuan setiap tiga bulan, dalam laporan tersebut ada pencapaian kegiatan yang dilakukan hingga berapa persen, sehingga ini bisa dilihat sampai realisasi anggaran. Apabila ternyata di bawah rata-rata dan hasil laporannya merah, Satuan Kerja Perangkat Daerah (SKPD) harus memberikan penjelasan tentang alasan tidak mencapai target sesuai dengan perencanaan anggaran. Pengajuan itu langsung ke Walikota Semarang. Selain itu, dalam setiap kegiatan selalu ada pemantauan evaluasi tidak hanya melalui Surat Pertanggungjawaban (SPJ) tetapi juga menggunakan sistem online dengan Sekretariat Kota Semarang. Adapun setiap Satuan Kerja Perangkat Daerah (SKPD) di Kota Semarang harus memiliki setidaknya satu personel yang bertugas memasukkan laporan kegiatan ke dalam aplikasi online yang nantinya dapat dipantau oleh Bappeda. Sehingga dengan cara ini diharapkan setiap Satuan Kerja Perangkat Daerah (SKPD) mampu menyerap anggaran secara maksimal sesuai dengan target yang telah ditentukan. Karena itu, Bappeda Kota Semarang selalu bekerja dengan mengikuti target. Tujuh bidang di Bappeda Kota Semarang memiliki aktivitas sendiri. Semua kegiatan yang ada harus diatur secara tepat waktu sehingga dapat dikontrol dengan baik dan tidak tiba pada waktu yang bersamaan. Bappeda Kota Semarang harus berkomitmen terhadap anggaran yang diberikan dan kegiatan yang direncanakan, oleh karena itu harus diwujudkan sesuai dengan jadwal. Lebih lanjut, sumber daya organisasi tidak hanya didukung oleh sumber daya keuangan tetapi juga didukung oleh fasilitas dan infrastruktur yang memadai. Layanan publik yang ada juga perlu didukung oleh fasilitas dan infrastruktur untuk mempercepat layanan. Bappeda Kota Semarang juga terus mengembangkan teknologi informasi sebagai dukungan untuk layanan Bappeda Kota Semarang baik dari segi peralatan seperti Personal Computer (PC), printer, komputer dan perangkat lunak serta aplikasi yang mendukung implementasi kegiatan pemberdayaan masyarakat. Pada Tabel 1, secara lebih rinci disebutkan beberapa jenis perangkat keras/lunak sebagai dukungan teknologi informasi.

Tabel 1. Dukungan Teknologi Informasi Smart City Melalui Program Gerbang Hebat

\begin{tabular}{|c|c|c|c|}
\hline No. & Produk & Smart City IT & $\begin{array}{c}\text { Smart City Non } \\
\text { IT }\end{array}$ \\
\hline 1. & $\begin{array}{l}\text { Sakip telah } \\
\text { diintegrasikan } \\
\text { melalui entri } \\
\text { tunggal. } \\
\text { Bahkan } \\
\text { integrasi ini } \\
\text { menjadi tuan } \\
\text { rumah untuk } \\
\text { menampung } \\
\text { beberapa } \\
\text { Bank dan } \\
\text { Taspen. }\end{array}$ & $\begin{array}{l}\text { Pengembangan } \\
\text { internal melalui } \\
\text { tata kelola dunia } \\
\text { maya, yaitu: } \\
\text { persiapan } \\
\text { kebijakan, sumber } \\
\text { daya manusia, } \\
\text { aplikasi dan } \\
\text { infrastruktur. } \\
\text { Pengembangan } \\
\text { eksternal melalui } \\
\text { dunia maya, yaitu } \\
\text { aplikasi interaktif } \\
\text { dan informatif } \\
\text { untuk publik } \\
\text { sejalan dengan } \\
\text { penguatan } \\
\text { Keterbukaan } \\
\text { Informasi Publik } \\
\text { (KIP). }\end{array}$ & 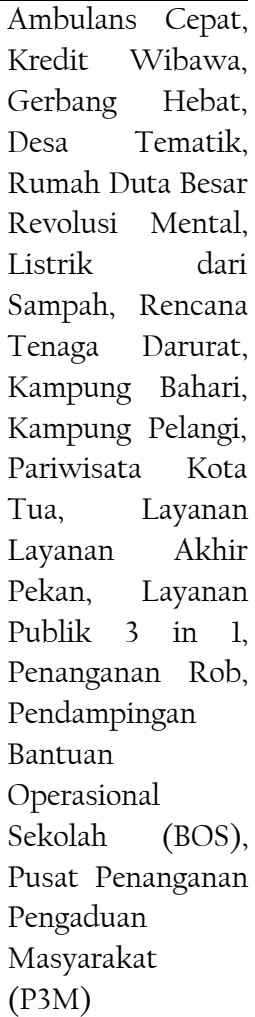 \\
\hline 2. & $\begin{array}{l}\text { Infrastruktur } \\
\text { Seluruh } \\
\text { jaringan OPD } \\
\text { (organisasi } \\
\text { perangkat } \\
\text { regional) telah } \\
\text { mengintegrasik } \\
\text { an jaringan } \\
\text { serat optik } \\
\text { (FO) bahkan ke } \\
\text { tingkat } \\
\text { kecamatan dan } \\
\text { kecamatan. }\end{array}$ & 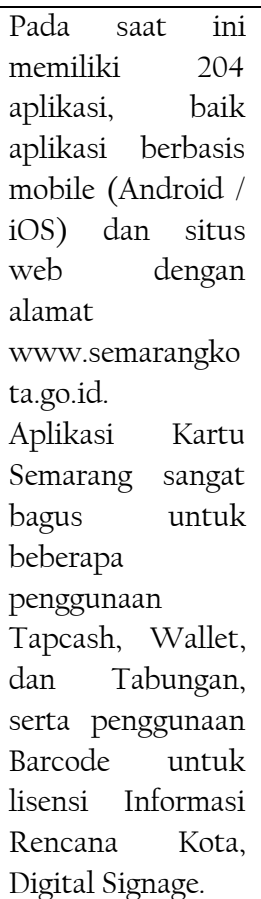 & \\
\hline
\end{tabular}




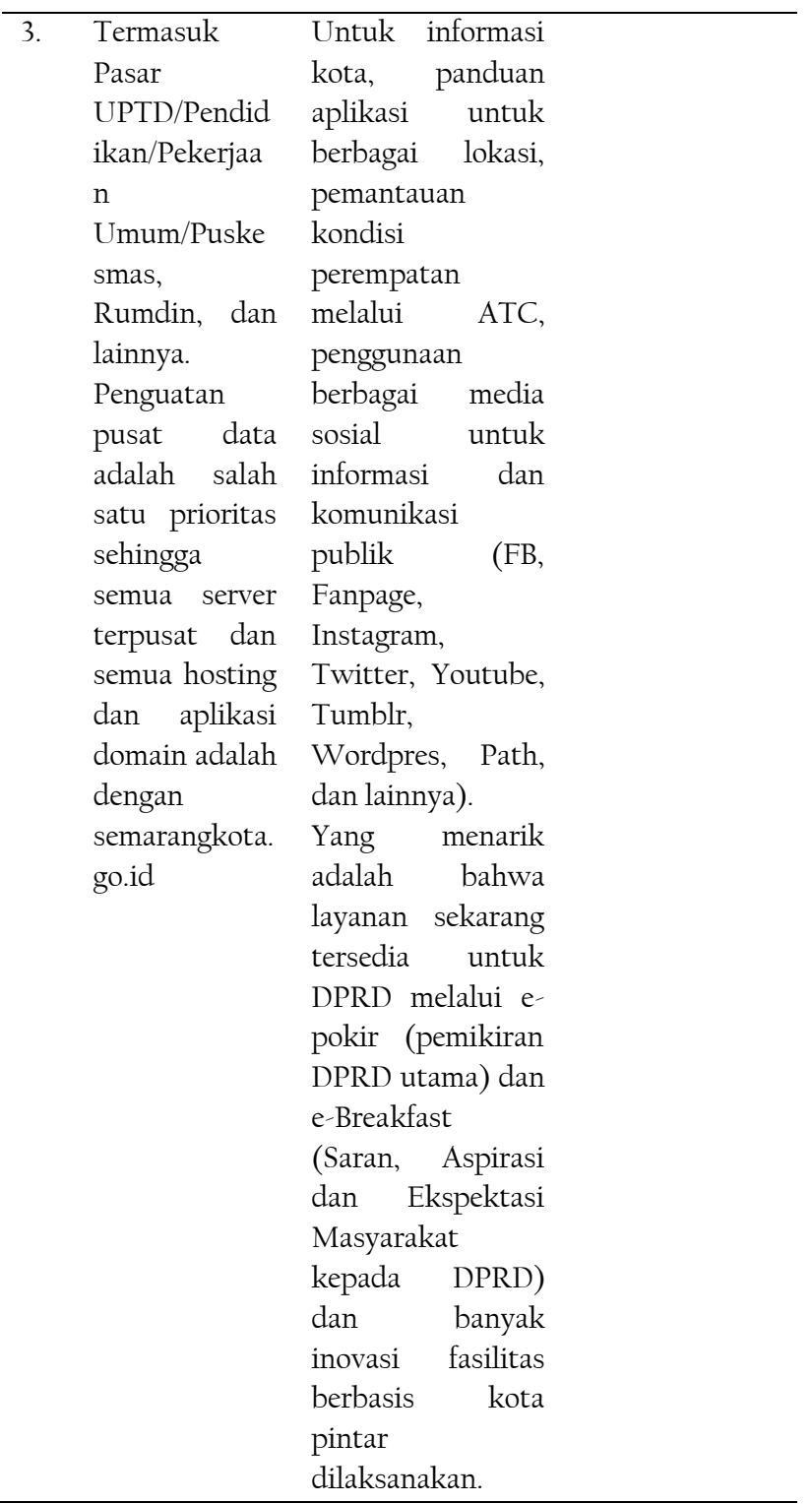

Sumber: Semarangkota.go.id, 2019

Lebih lanjut, sumber daya keuangan dan fasilitas serta sumber daya juga harus didukung oleh sumber daya manusia, di mana sumber daya ini merupakan sumber daya yang sangat penting dalam menjalankan suatu organisasi. Penempatan posisi personil di Bappeda Kota Semarang selain melihat keterampilan dan kompetensi mereka, tingkat pendidikan juga menjadi pertimbangan. Setiap individu diatur langsung oleh kepala Bappeda Kota Semarang yang ditandai dengan adanya surat keputusan atau surat keputusan dari kepala Bappeda Semarang. Selain itu, setiap bagian memiliki deskripsi masingmasing pekerjaan yang harus dipahami oleh masing-masing personil. Dalam perkembangannya, moratorium berdampak pada ketersediaan karyawan di Bappeda Kota Semarang yang sekarang sangat terbatas sementara ada lebih banyak pekerjaan. Idealnya, setiap sub-sektor memiliki 2 staf, tetapi kenyataannya di Bappeda Kota Semarang rata-rata hanya ada 1 staf. Sedangkan tingkat kompetensi dan tingkat pemahaman masing-masing staf berbeda-beda. Jika sub-sektor hanya memiliki 1 staf, sementara kompetensi dan pemahamannya kurang, maka tugas tersebut tidak akan dimaksimalkan, sehingga tidak dapat dihindari bahwa sub-direktorat harus menyelesaikannya.
Ketiga, komunikasi antara lembaga pelaksana menunjukkan mekanisme prosedur yang dicanangkan untuk mencapai tujuan dan sasaran program. Implementasi suatu program membutuhkan dukungan dan koordinasi dengan lembaga lain. Sehingga diperlukan koordinasi dan kerja sama antarlembaga untuk keberhasilan suatu program. Dalam merumuskan kebijakan Kota Cerdas Semarang melalui salah satu program Gerbang Hebat, pemerintah sebagai aktor negara telah menetapkan Keputusan Walikota Semarang Nomor 100/495 tahun 2017 tentang Pembentukan Tim Pengembangan Kota Cerdas. Hubungan koordinasi ini dilakukan melalui pertemuan rutin sesuai dengan jadwal yang telah ditentukan, dan pertemuan yang sifatnya insidental. Jadi tidak hanya melalui pertemuan tim teknis, tetapi setiap hari ada komunikasi antara Bappeda Kota Semarang dan Satuan Kerja Perangkat Daerah (SKPD) terkait lainnya. Memang, tidak ada kegiatan khusus yang dilakukan untuk memperkuat hubungan koordinasi antara Bappeda Kota Semarang dan Satuan Kerja Perangkat Daerah (SKPD) terkait, hanya melalui pertemuan tersebut. Terkadang jadwal survei lapangan dan rapat internal harus menyesuaikan jadwalnya di Satuan Kerja Perangkat Daerah (SKPD) yang relevan, karena bagaimanapun prioritas utama adalah tugas pimpinan Satuan Kerja Perangkat Daerah (SKPD) yang relevan. Inilah yang menjadi dilema bagi Bappeda Kota Semarang dalam memberikan layanan cepat dan tepat waktu sesuai dengan Standar Operating Procedure (SOP) yang disiapkan. Ada keinginan agar Bappeda Kota Semarang dapat memiliki tim teknis dari Bappeda sendiri yang kompeten di bidangnya, tetapi hal ini tidak mungkin dilakukan karena sumber daya manusia yang terbatas, selain itu ada peraturan daerah yang mengatur tupoksi dari Kota Semarang. Bappeda termasuk tim teknis itu sendiri. Kebijakan yang dibuat oleh Pemerintah Kota Semarang pada kenyataannya justru menciptakan hambatan bagi pemberdayaan masyarakat di kota Semarang.

Keempat, karakteristik lembaga pelaksana dilihat dari bagaimana struktur organisasi mendukung, nilai-nilai yang berkembang dan komunikasi internal yang dibangun dalam organisasi. Kehadiran Kepala Sub Bagian tidak hanya melaksanakan tugasnya tetapi juga melaksanakan tugas struktural sebagai kepala sub-sektor, misalnya, untuk mewakili kepala lapangan yang menghadiri rapat. Ini tidak dapat digantikan oleh staf karena kompetensi mereka yang terbatas. Permasalahan ini telah dicoba, yaitu dengan mengajukan aplikasi ke Dinas Pencatatan Sipil Kota Semarang. Selain itu, terkait dengan nilai-nilai yang berkembang dan yang selalu ditanamkan di seluruh anggota organisasi, Bappeda Kota Semarang sendiri sebagai organisasi pelayan publik yang tentunya telah menanamkan nilai-nilai. Nilai-nilai ini terkandung dalam dekrit Bappeda Kota Semarang dan Kode Etik Bappeda untuk Kota Semarang. Pengumuman Bappeda Kota Semarang pada dasarnya berisi komitmen Bappeda untuk memberikan layanan maksimal kepada masyarakat, sedangkan kode etik untuk karyawan Bappeda Kota Semarang berisi etika karyawan Bappeda Kota Semarang sebagai pelayan negara yang bertugas pertama kali adalah melayani masyarakat.

Kelima, Sikap pelaksana merupakan hal penting dalam implementasi kebijakan. Pembuatan kebijakan harus menempatkan sumber daya manusia yang berkompeten sesuai dengan kebijakan yang akan disusun. Penempatan sumber daya manusia harus memiliki kemampuan ketrampilan dalam 
melakukan analisis permasalahan. Oleh karena itu, dari sejak 2009 sampai dengan saat ini selalu diadakan pendampingan untuk teknis pemberdayaan masyarakat. Bappeda Kota Semarang senantiasa melibatkan pihak Perbankan, BUMN/BUMD, swasta serta bantuan CSR. Proses sinergitas memang membutuhkan cukup banyak waktu, sehingga diperlukan adanya komitmen seluruh anggota organisasi dalam melaksanakan. Soft skill memang penting adanya, karena dengan tingkat kemampuan dan pemahaman yang cukup akan tugas dan tanggung jawab serta pengetahuan yang luas tentunya akan memberikan kemudahan bagi personil dalam melaksankan tugas serta memahami tugas dan informasi yang diberikan. Sedangkan bagi pemimpinpun tidak perlu harus turun tangan langsung dan bahkan menjelaskan hingga berulang kali mengenai suatu tugas atau pekerjaan yang harus diselesaikan. Harapannya ada idealisme baru yang muncul dalam diri seorang pegawai sehingga nantinya dapat memberikan iklim yang positif bagi organisasi publik khususnya Bappeda Kota Semarang. Sebab pegawai Bappeda Kota Semarang tidak semuanya muda dan baru yang memiliki jiwa idealis dan kreatif.

Pada pelaksanaan Gerbang Hebat terdapat prinsip keterlibatan individu, pendekatan sistem terhadap manajemen yang didalamnya terdapat proses pemahaman peran dan tanggung jawab setiap individu, serta prinsip penigkatan terus menerus salah satunya adalah peningkatan sumber daya manusia. Ketiga prinsip tersebut memberikan pengaruh positif untuk mendorong pegawai Bappeda Kota Semarang untuk dapat bekerja secara profesional bukan hanya sekedar berorientasi pada tugas saja namun menanamkan dalam diri mereka untuk bekerja dengan ikhlas sebagai abdi negara untuk memberikan pelayanan yang terbaik bagi masyarakat.

Beberapa masyarakat merasa peran Bappeda Kota Semarang sudah cukup baik, terlebih dalam mendukung upaya pemberdayaan masyarakat dalam penanggulangan kemiskinan melalui Gerbang Hebat. Selain itu, juga disediakan saluran jika terdapat keluhan masyarakat dimana dapat disampaikan melalui layanan aduan yang tersedia bisa melalui P5, media cetak Suara Merdeka pada kolom piye jal, lewat sms, yahoo messenger, twitter, online langsung pada website Bappeda Kota Semarang atau Semarang Hebat, ataupun melalui surat aduan yang ditujukan kepada Kepala Bappeda Kota Semarang. Setelah itu akan ditindaklanjuti dengan meninjau terlebih dahulu permasalahan yang diadukan, setelah ada disposisi bagian pengawasan atau controlling melakukan langkah selanjutnya melalui crosscheck permasalahan yang ada. Lebih lanjut, Bappeda Kota Semarang dalam menghimbau menggunakan upaya pendekatan kepada masyarakat dengan sosialisasi berbagai akses pelayanan yang dapat digunakan masyarakat.

Melalui Program Gerbang Hebat, Pemerintah Kota Semarang mendapat penghargaan Smart City. Sehingga upaya perbaikan dan peningkatan akses pelayanan publik pada masyarakat harus senantiasa dilakukan secara periodik dan berkelanjutan. Setiap pelayanan yang kurang dan tidak memuaskan bisa disampaikan dengan memberika kritik dan saran bagi kinerja Pemerintah Kota Semarang melalui media yang sudah tersedia bahkan bisa disampaikan secara langsung kepada petugas untuk nantinya dapat menjadi masukkan. Namun belum semua masyarakat mau memberikan kritik dan sarannya bahkan tidak pernah melakukan pengaduan hanya karena takut salah bicara, bahkan lebih jauhnya lagi mereka takut nantinya permohonan atau aduan mereka justru merugikan nama baik mereka. Mereka lebih memilih membiarkan saja dan menganggap apa yang terjadi itu sudah biasa.

Keenam, lingkungan sosial, ekonomi dan politik menunjukkan bahwa lingkungan dapat mempengaruhi keberhasilan implementasi kebijakan itu sendiri. Kebijakan publik dibuat oleh pemerintah untuk mengatasi masalah publik. Karena itu, suatu kebijakan harus disesuaikan dengan kondisi lingkungan di mana kebijakan itu dijalankan. Kota Semarang adalah kota Perdagangan dan Jasa, di mana banyak sektor ekonomi akan selalu dan terus tumbuh dari tahun ke tahun, terutama sektor perdagangan dan jasa. Diharapkan bahwa lebih banyak investor akan tertarik berinvestasi di kota Semarang. Hal tersebut dikarenakan didukung oleh institusi profesional dan nantinya dapat memberikan kemudahan bagi pihak ketiga untuk berinvestasi di kota Semarang. Salah satu lembaga tersebut adalah lembaga yang memiliki kewenangan untuk merencanakan pembangunan daerah, yaitu Bappeda Kota Semarang. Peningkatan investasi tentu akan meningkatkan Pendapatan Asli Daerah (PAD) Kota Semarang. Terlepas dari aspek ekonomi dan sosial, juga dapat dilihat dari sisi politik dimana pemerintah kota Semarang juga berkomitmen untuk memberikan layanan yang sangat baik kepada masyarakat.

\section{Kesesuaian dengan prinsip-prinsip Smart Society}

Melalui program Gerbang Hebat, fungsi masyarakat semakin besar dalam proses pemberdayaan. Gerbang Hebat dilakukan melalui pola tribina, yaitu 1) pembangunan manusia, adalah pemenuhan layanan dasar dan kebutuhan dasar, peningkatan pengetahuan dan keterampilan dan perubahan moral, karakter dan pola pikir; 2) pengembangan masyarakat, dengan mendorong perubahan dan peningkatan lingkungan kaum miskin agar dapat menjalankan kehidupan dan bisnis dengan aman, sehat dan nyaman serta mendorong Perilaku Hidup Bersih dan Sehat (PHBS); 3) pengembangan bisnis, dengan menciptakan pengusaha baru independen, mendorong pemberdayaan bisnis keluarga untuk meningkatkan penghasilan keluarga, mendorong peluang kerja melalui perluasan jaringan. Selain itu, Pemerintah Kota Semarang mencari strategi untuk mempercepat kemiskinan dan pengurangan pengangguran di kota Semarang melalui Gerbang Hebat sebagai dukungan bagi terwujudnya Smart Society. Perencanaan dilakukan melalui integrasi program dan penguatan koordinasi yang melibatkan partisipasi masyarakat dan peran aktif, BUMN/BUMD, perbankan, dunia bisnis, PTN/PTS, organisasi masyarakat, dan LSM.

Program Gerbang Hebat dibagi menjadi beberapa kegiatan, yang melalui proyek percontohan. Pertama, Desa Tematik. Kelurahan atau yang sering disebut dengan Desa Tematik adalah salah satu inovasi dari Pemerintah Kota Semarang untuk mengatasi masalah pemenuhan kebutuhan dasar, terutama dalam meningkatkan kualitas lingkungan rumah miskin dan infrastruktur dasar perumahan. Desa Tematik adalah titik sasaran untuk beberapa wilayah Kelurahan yang telah diperbaiki. Kedua, program e-warung Kelompok Bisnis Bersama (KUBE). Hal ini adalah bentuk Kelompok Bisnis Bersama (KUBE) dalam Program Keluarga Harapan di mana targetnya adalah penerima miskin Program Keluarga Harapan (PKH). Tujuan program e-warung Kelompok Bisnis Bersama (KUBE) 
adalah untuk mendistribusikan bantuan kepada orang miskin tidak dalam bentuk tunai, tetapi dalam bentuk bahan-bahan dasar. Kebutuhan dasar yang dapat diperoleh oleh masyarakat miskin di e-warung adalah beras, gula, minyak goreng, dan tepung. Nantinya, akan disediakan $3 \mathrm{~kg}$ daging dan gas LPG. Ketiga, RDRM (Rumah Duta Revolusi Mental). Terjadinya fenomena meningkatnya kasus kekerasan terhadap perempuan dan anak-anak setiap tahun di kota Semarang membuat masyarakat membutuhkan respon cepat dari pemerintah kota Semarang dalam memfasilitasi pengaduan tindakan kekerasan terhadap perempuan dan anak-anak. Masih ada keluhan tentang penanganan korban yang bersifat parsial atau tidak komprehensif, yaitu mencapai kekuasaan atau menjadi produktif kembali. Salah satu alasannya adalah karena proses panjang koordinasi pemangku kepentingan. Rumah Duta Mental Revolution (RDRM) yang dibangun oleh Pemerintah Kota Semarang datang sebagai solusi untuk mengatasi masalah tersebut. Melalui RDRM ini, tingkat keamanan masyarakat kota Semarang menjadi lebih baik. Ini sebagai wujud dukungan nyata dari program Pemerintah Kota Semarang kepada Pemerintah Pusat dan Provinsi Jawa Tengah dalam upaya memberikan perlindungan dan pemberdayaan anak-anak dan perempuan serta mewujudkan Kota Tangguh khususnya di bidang kesehatan fisik dan psikososial di Semarang. Kota melalui pembentukan sistem pendukung psikologis berbasis teknologi.

\section{Manfaat yang dirasakan oleh Badan Pelaksana dan Komunitas}

Manfaat dari Desa Tematik yang dirasakan oleh masyarakat adalah pemenuhan dan peningkatan fasilitas dan infrastruktur lingkungan berupa fasilitas publik dan fasilitas sosial yang lebih baikdan terorganisir. Terdapat pertumbuhan dan peningkatan ekonomi lokal yang berpotensi meningkatkan pendapatan keluarga. Hal tersebut mendukung merek dagang daerah menjadi ikon, dapat memiliki pengaruh positif pada penduduk lokal seperti perubahan pola pikir dan perilaku masyarakat, pemberdayaan masyarakat. Diharapkan juga dapat memberikan pengaruh positif dan daya tarik bagi desa-desa lain di Kelurahan dan Kelurahan lain untuk dipicu dan dimotivasi untuk mewujudkan masalah tematik yang serupa. Selain itu, munculnya titik kunjungan baru di setiap kecamatan yang tidak semuanya terpusat di tingkat kota, sebagaimana pendirian pusat dan galeri rumah, yang mendukung pengembangan potensi dan ikon kota Semarang. Nantinya, diharapkan bahwa pemberi Corporate Social Responsibility (CSR) akan dapat mereplikasi Desa Tematik di daerah/desa lain.

Manfaat program e-warung Kelompok Bisnis Bersama (KUBE) adalah mendukung implementasi Gerbang Hebat dalam sinergi program pengurangan kemiskinan. Oleh karena itu, Pemerintah Kota Semarang mereplikasi pada 2016 sebanyak 61 titik baru yang tersebar di 53 Kelurahan 16 Kecamatan di seluruh Semarang, dengan mengalokasikan anggaran untuk kios rehabilitasi yang ditunjuk dan melengkapi infrastruktur program e-warung Kelompok Bisnis Bersama (KUBE) dengan dana Rp. 30.000.000 per warung. Untuk memenuhi kebutuhan masyarakat miskin Kota Semarang akan bahan dasar, diharapkan replikasi program e-warung Kelompok Bisnis Bersama (KUBE) Kota Semarang dapat ditindaklanjuti di seluruh Kelurahan di Kota Semarang dengan tahapan sebagai berikut melalui Amandemen Anggaran 2016 mereplikasi 61 ewarung Kelompok Bisnis Bersama (KUBE) di 53 Kelurahan 16 Kecamatan dengan anggaran @ Rp 30 juta, melalui Amandemen APBD 2017 mereplikasi e-warung Kelompok Bisnis Bersama (KUBE) di 54 Kelurahan 16 Kecamatan dengan anggaran @ Rp 30 juta, melalui APBD Murni 2018 yang mereplikasi e-warung Kelompok Bisnis Bersama (KUBE) di 70 Kelurahan 16 Kecamatan dengan anggaran @ Rp 30 juta, melalui bantuan Corporate Social Responsibility (CSR) dan/atau sumber pendanaan non-APBD di Kota Semarang untuk menambah/melipatgandakan distribusi replikasi program ewarung Kelompok Bisnis Bersama (KUBE).

Manfaat Rumah Duta Revolusi Mental (RDRM). Keberadaan RDRM menciptakan program "rumah" untuk layanan kesehatan fisik dan psikososial yang mencakup perlindungan anak dan pemberdayaan perempuan dengan memperkuat jaringan pemangku kepentingan berbasis teknologi di kota Semarang. Layanan kesehatan fisik dan psikososial termasuk pencegahan, pemulihan, advokasi, dan pemberdayaan yang cepat dan tepat dengan melibatkan berbagai pemangku kepentingan yang relevan juga tersedia. Jadi dampaknya terhadap penggunaan situs web atau aplikasi media sosial di masyarakat Kota Semarang semakin meningkat. Oleh karena itu, dirancang untuk menyediakan fasilitas call center atau situs web atau aplikasi media sosial kepada masyarakat Kota Semarang. Secara khusus, kehadiran RDRM menciptakan peningkatan sebagai berikut peningkatan bentuk layanan kesehatan fisik dan psikososial yang terintegrasi dengan sistem aplikasi/teknologi, pengembangan pusat krisis untuk tindakan kekerasan terhadap perempuan dan anak-anak, meningkatkan Sumber Daya Manusia (SDM) wanita, memperkuat pengarusutamaan gender, meningkatkan kualitas perlindungan perempuan, meningkatkan peran perempuan, pengurangan kemiskinan terpadu.

\section{KESIMPULAN}

Pelaksanaan program Gerakan Bersama Penanggulangan Kemiskinan Dan Pengangguran Melalui Harmonisasi Ekonomi, Pendidikan, Etos Dan Ekosistem Masyarakat (Gerbang Hebat) di Kota Semarang dilakukan melalui 3 (tiga) kegiatan yaitu Desa Tematik, program e-warung Kelompok Bisnis Bersama (KUBE), dan Duta Revolusi Mental Rumah (RDRM). Semua kegiatan ini adalah langkah yang diambil oleh Pemerintah Kota Semarang untuk mewakili realisasi Smart Society. Pada upaya mendukung keberlanjutan program ini, masih diperlukan semangat kerja dan komitmen tinggi dari para pelaku yang terlibat, yaitu Satuan Kerja Perangkat Daerah (SKPD) terkait, Perbankan, BUMN/BUMD, sektor swasta, komunitas bisnis, organisasi masyarakat, Lembaga Swadaya Masyarakat (LSM), dan bantuan Corporate Social Responsibility (CSR) dalam kemiskinan pengentasan untuk menciptakan masyarakat yang lebih sejahtera. Penyajian basis data yang valid, akurat, tepat sasaran, objektif, dan terkini dimana berdasarkan nama berdasarkan alamat serta berdasarkan potensi dan wilayah juga masih merupakan tantangan dan pemantauan maupun evaluasi ketika program telah selesai, tetapi juga harus ada indikator keberhasilan program yang disusun sebagai bahan untuk evaluasi lapangan dan timbal balik kegiatan pemberdayaan masyarakat yang telah dilakukan. Selain itu, partisipasi masyarakat memiliki peran penting dalam mewujudkan tata kelola masyarakat berbasis digital. Hal ini untuk memastikan 
bahwa kegiatan yang memang sesuai dengan kebutuhan masyarakat, serta memastikan bahwa kegiatan ini adalah kegiatan yang berkelanjutan dan dapat membawa masyarakat menuju kemandirian. Faktor pendukung implementasi program Gerbang Hebat yakni standar dan sasaran kebijakan, komunikasi antar lembaga pelaksana, karakteristik lembaga pelaksana, sikap lembaga pelaksana, serta lingkungan eksternal yang baik. Adapun faktor pengahambat yakni keterbatasan sumber daya organisasi khususnya SDM.

\section{REFERENSI}

Agustino, Leo. (2006). Dasar-Dasar Kebijakan Publik. Bandung: CV. Alfabeta.

Allen, B., Tamindael, L. E., Bickerton, S. H., \& Cho, W. (2019). Does citizen coproduction lead to better urban services in smart cities projects? An empirical study on e-participation in a mobile big data platform. Government Information Quarterly, May 2018, 101412. https://doi.org/10.1016/j.giq.2019.101412

Awaliyah Rizky. (2016). Implementasi Program Percepatan Penanggulangan Kemiskinan Oleh Dinas Kesejahteraan Sosial Kota Samarinda. Administrasi Negara, Volume 4 ,(1), 191.

Bouzguenda, I. (2019). Towards smart sustainable cities: A review of the role digital citizen participation could play in advancing social sustainability. Sustainable Cities and Society, 50(May), 101627. https://doi.org/10.1016/j.scs.2019.101627

Badan Pusat Statistik. (2020). Presentase Penduduk Miskin September 2019 turun menjadi 9,22 persen. Dapat diakses melalui

https:/www.bps.go.id/pressrelease/2020/01/15/1743/persen tase-penduduk-miskin-september-2019-turun-menjadi-922-persen.html, tanggal 02 Maret 2020

De Guimarães, J. C. F., Severo, E. A., Felix Júnior, L. A., Da Costa, W. P. L. B., \& Salmoria, F. T. (2020). Governance and quality of life in smart cities: Towards sustainable development goals. Journal of Cleaner Production, 253. https://doi.org/10.1016/j.jclepro.2019.119926

Fietkiewicz, K. J., Mainka, A., \& Stock, W. G. (2017). eGovernment in cities of the knowledge society. An empirical investigation of Smart Cities' governmental websites. Government Information Quarterly, 34(1), 75-83. https://doi.org/10.1016/j.giq.2016.08.003

Heaton, J., \& Parlikad, A. K. (2019). A conceptual framework for the alignment of infrastructure assets to citizen requirements within a Smart Cities framework. Cities, 90(January), 32-41. https://doi.org/10.1016/j.cities.2019.01.041

Horgan, D., \&e Dimitrijević, B. (2019). SC. Sustainable Cities and Society, 101550. https://doi.org/10.1016/j.scs.2019.101550

Johnson, P. A., Robinson, P. J., \& Philpot, S. (2019). Type, tweet, tap, and pass: How smart city technology is creating a transactional citizen. Government Information Quarterly, February, 101414. https://doi.org/10.1016/j.giq.2019.101414

Patel, Y., \& Doshi, N. (2019). Social implications of smart cities. Procedia Computer Science, 155(2018), 692-697. https://doi.org/10.1016/j.procs.2019.08.099
Peraturan Walikota Semarang Nomor 26 Tahun 2018 Tentang Rencana Induk Semarang Kota Cerdas (Masterplan Semarang Smart City). (2018)

Sukardi. (2003). Metodologi Penelitian Pendidikan: Kompetensi dan Praktiknya. Jakarta: Bumi Aksara.

Sulhan, M., \& Sasongko, T. (2017). Implementasi Kebijakan Program Penanggulangan Kemiskinan Melalui Kertu Penjamin Sosial Dan Kartu Indonesia Pintar Pada Masyarakat (Studi Kasus Di Kelurahan Kauman Kota Malang). Jurnal Ilmu Sosial Dan Ilmu Politik Universitas Tribhuwana Tunggadewi, 6(1), 101281.

Supangkat, S. H., \& Arman, A. A. (2018). The Implementation of Garuda Smart City Framework for Smart City Readiness Mapping in Indonesia. 4, 169-176. 